\title{
Review
}

\section{Purification and Application of Lipases from Pseudomonas Species}

\author{
Saadat Ullah $^{\text {a*, Ijaz Malook }}{ }^{\mathrm{a}}$, Khair Ul Bashara ${ }^{\mathrm{a}}$, Mehvish Riaz ${ }^{\mathrm{a}}$, Muhammad \\ Mudasar Aslam ${ }^{\mathrm{b}}$, Zia Ur Rehman ${ }^{\mathrm{a}}$, Irfan Malook ${ }^{\mathrm{c}}$, Muhammad Fayyaz \\ and Muhammad Jamil ${ }^{\mathrm{a}}$ \\ ${ }^{a}$ Department of Biotechnology and Genetic Engineering, Kohat University of Science and \\ Technology, KUST, Kohat-26000, Pakistan \\ ${ }^{\mathrm{b}}$ Lab of Plant Physiology and Proteomics, Department of Botany, Kohat University of Science \\ and Technology, KUST, Kohat-26000, Pakistan \\ ${ }^{\mathrm{c}}$ Department of Pharmacology, Institute of Basic Medical Sciences, Khyber Medical University, \\ KMU, Peshawar, Pakistan
}

(received October 20, 2015; revised Feburary 23, 2016; accepted Feburary 29, 2016)

\begin{abstract}
Lipases are important hydrolytic enzymes that hydrolyze long chain triacylglycerol into diacylglycerol, monoacylglycerol, glycerol and fatty acids. Lipases are found in microorganisms, fungi, plants and animals. Commercially, useful extracellular lipases are isolated from different bacterial species, including Bacillus, Achromobacter, Alcaligenes, Arthrobacter, Pseudomonas, Staphylococcus and Chromobacterium species. Among the Pseudomonas species, Pseudomonas aeruginosa, P. cepacia and $P$. fluorescence are the major producers of lipases. Bacterial lipases have great industrial applications because of their stability, selectivity and broad substrate specificity. Due to their large scale application in industrial sectors, attention is given to isolate Pseudomonas lipases. In this review, purification strategies for lipases isolated from Pseudomonas species have been focussed.
\end{abstract}

Keywords: lipases, Pseudomonas, industrial applications, purification strategies

\section{Introduction}

Lipases are ubiquitous enzymes widely present in many species of animals, plants, bacteria, yeast and fungi (Dong et al., 1999). Lipases hydrolyze long chain triacylglycerol into diacylglycerol, monoacylglycerol, glycerol and fatty acids (Yamamoto and Fujiwara, 1995). Bacterial lipases have great industrial applications because of their stability, selectivity and broad substrate specificity. Lipases can be isolated from gram negative as well as gram positive bacteria.

Microorganisms having potential to produce lipases can be found in various habitats including industrial wastes, vegetable-oil processing factories, dairies, soil contaminated with oil, oil seeds, decaying food, compost heaps, coal tips, and hot springs (Qamsari et al., 2011). Among microorganisms, several species of bacteria, yeast and fungi are potential producers of extracellular lipases (Veerapagu et al., 2013). Additionally, many, if not all, commercially useful extracellular lipases are isolated from different bacterial species, including Bacillus achromobacter, Alcaligenes, Arthrobacter, *Author for correspondence; E-mail:sadatullah_86@yahoo.com
Staphylococcus chromobacterium and Pseudomonas (Qamsari et al., 2011; Gupta et al., 2004).

Among the Pseudomonas species, P. aeruginosa, $P$. cepacia and $P$. fluorescence are the major producers of lipases (Stoyanova et al., 2012). Pseudomonas are motile, rod shaped, aerobic, gram negative and non fermentative bacteria. Pseudomonas is present in soil, water, animals and plants.

Microbial enzymes have various industrial applications in food, detergent, paper, leather, pharmaceutical and textile industries (Hasan et al., 2006). Pseudomonas lipases are widely used in food, pharmaceutical, detergent and textile industries for quality improvements of food items, giving proper shape to pharmaceuticals products, for removal of oil stains from fabrics by hydrolysis of fats and increase fabric absorbance, respectively (Sharma et al., 2001). Due to their large scale application in industrial and health sectors, attention is given to isolate bacterial lipases. In this mini review, lipases from Pseudomonas species have been foussed.

Sources of lipases. Lipases are found in living organism including prokaryotes bacteria and archaea and 
eukaryotes fungi, plants and animals (Cai-hong et al., 2008). Microbial lipases are more important as compared to plant and animal lipases because of their easy genetic modification, growth on inexpensive media and higher catalytic activities.

In biotechnological applications, mostly bacterial and fungal lipases are used among microbial lipases. The extracellular bacterial lipases are more important because these enzymes are easily produced (Palekar et al., 2000; Jaeger et al., 1994). The lipase producing bacterial species include Achromobacter, Alcaligenes, Arthrobacter, Bacillus, Burkholderia, Chromobacterium and Pseudomonas. Of these, lipases obtained from Pseudomonas bacteria are extensively used for a variety of biotechnological applications ( Beisson et al., 2000; Pandey et al., 1999).

Pseudomonas as a lipase producer. Lipases are produced and isolated from both gram positive and gram negative bacteria. Gram negative bacteria contribute to a larger part of bacterial lipases. Genus Pseudomonas is the most important gram negative genus, containing at least seven lipase producing species i.e., P. aeruginosa, P. alcaligenes, P.fragi, P. glumae, P.cepacia, P. fluorescens and $P$. putida (Kojima et al., 2003).

Purification strategies for lipases. The literature represents different purification strategies for lipases including chromatography, aqueous two-phase systems, Reversed micellar systems, Immuno purification and membrane processes. After production of extracellular lipases microbial cells are removed from the fermented media by centrifugation or filtration. Organic solvents, ammonium sulphate precipitation and ultra filtration are used to concentrate the cell free supernatant. $80 \%$ purification protocols involve precipitation, in which $60 \%$ using ammonium sulphate, $35 \%$ using $\mathrm{HCl}$ or ethanol. After precipitation step, chromatographic techniques including affinity chromatography, ion exchange chromatography and gel filtration are used for further purification (Pabai et al., 1995). Precipitation methods give $87 \%$ yield as compared with other techniques (Aires-Barros et al., 1994).

Chromatography. Chromatography is generally used for the purification of extracellular lipases, sometimes one type of chromatographic technique is not sufficient to achieve the required level of purity. Therefore, different chromatographic techniques are used to get the required purity. Ion exchange chromatography is one of the most commonly used chromatographic techniques. It is used in $67 \%$ of the purification procedures. Mostly diethylaminoethyl (DEAE) group is used as an anion exchange (58\%) while carboxymethyl (CM) as a cation exchange (20\%). The most frequently employed ion-exchangers are the diethylaminoethyl (DEAE) group in anion exchange (58\%) and the carboxymethyl $(\mathrm{CM})$ in cation exchange $(20 \%)$. Commonly strong ion exchangers on the basis of triethylaminoethyl groups (Veeraragavan et al., 1990) and Q-Sepharose (Menge et al., 1991) are used in lipase purification. Gel filtration is the second common purification technique used in $60 \%$ of the purification procedures. Affinity chromatography used in $27 \%$ of the purification procedures whereas, hydrophobic interaction chromatography is used in $18 \%$ of purification procedures (Farooqui et al., 1994). A procedure used by Chartrain et al. (1993) for the purification of lipase from Pseudomonas aeruginosa MB5001 consists of three steps. The procedure involves concentration of lipase in crude extracts by using ultra filtration, ion exchange chromatography and gel filtration. Lee and Rhee (1993) purified lipase from Pseudomonas putida 3SK by using ion exchange chromatography and gel filtration. Sharon et al. (1998) purified an extracellular lipase from $P$. aeruginosa KKA- 5 by ammonium sulphate precipitation and chromatography.

Membrane processes. In downstream processing of lipase purification, membrane filtration has been used for removal of microbial cells and concentration of lipases in the supernatant of the spent media. The ultra filtration capillary membranes were studied for the purification of lipase from Pseudomonas fluorescens (Sztajer and Bryjak, 1989). Polyacrylonitrile and polysulphone capillary membranes were reported in literature for purification of lipases.

Aqueous two phase systems. The aqueous two phase systems consisting of two incompatible polymers such as dextran or PEG dissolved in water solution or phosphate buffer used for purification of proteins. The separation of proteins in aqueous two phase systems generally depend upon the physical and chemical properties including protein hydrophobicity, charge and size. The separations of proteins in aqueous two phase systems is affected by changing polymers, molecular mass of the polymer, $\mathrm{pH}$ and addition of salt to the system. This is an interesting procedure for the purification of lipases as compared to other procedures (Gupta et al., 1999; Albertsson et al., 1990). Literature 
reports various examples of lipase purification by using aqueous two phase systems (Table 1). During purification, the hydrophobicity of lipase is broken down by using detergents in aqueous two-phase systems. Pseudomonas cepacia lipase was purified by using detergent-based aqueous two-phase systems (Saxena et al., 2003; Terstappen et al., 1992).

Industrial applications of lipases. The microbial enzymes were introduced first into industry by Dr. Jokichi Takamine in the year 1894. Microbial lipases are used in food, paper, textile, pharmaceutical, leather and other industries (Hasan et al., 2006; Underkofler et al., 1957). Presently, about 4000 enzymes are known and nearly 200 are commercially used in various industries. Most commonly, the industrial lipases are of microbial origin. The total enzymes sale was a few million dollars annually until 1960s (Wilke, 1999) however, the demand for lipase is increasing day by day (Bornscheuer et al., 2002). The world enzymes demand is fulfilled by 12 producers and 400 suppliers. Approximately $60 \%$ of industrial enzymes are produced in Europe (Balashev et al., 2001). Mostly, 75\% commercial enzymes are hydrolases including carbohydrases, proteases, pectinases and lipases. These enzymes catalyse the hydrolysis of natural organic compounds into glucose, peptides, glycerol and fatty acids, respectively (Underkofler et al., 1957). The world commercial enzyme market was about 2 billion dollars in 2004 and reached to about 2.4 billion dollars in 2009. Lipases are about $4 \%$ of the world's enzyme market and due to their large scale applications in industrial sectors, special attention is given to lipases (Hasan, et

Table 1. Purification strategies used for bacterial lipase purification

\begin{tabular}{lll}
\hline \hline $\begin{array}{l}\text { Pseudomonas } \\
\text { spp }\end{array}$ & $\begin{array}{l}\text { Purification } \\
\text { strategies }\end{array}$ & Source \\
\hline $\begin{array}{l}\text { Pseudomonas } \\
\text { putida 3SK }\end{array}$ & $\begin{array}{l}\text { Ion exchange } \\
\text { chromatography } \\
\text { and gel filtration }\end{array}$ & $\begin{array}{l}\text { Lee and Rhee } \\
(1993)\end{array}$ \\
$\begin{array}{l}\text { Pseudomonas } \\
\text { aeruginosa }\end{array}$ & $\begin{array}{l}\text { Ammonium sulfate } \\
\text { precipitation and } \\
\text { chromatography }\end{array}$ & $\begin{array}{l}\text { Sharon } \text { et al. } \\
(1998)\end{array}$ \\
$\begin{array}{l}\text { Pseudomonas } \\
\text { fluorescens }\end{array}$ & Capillary membranes & $\begin{array}{l}\text { Sztajer and } \\
\text { Bryjak (1989) }\end{array}$ \\
$\begin{array}{l}\text { Pseudomonas } \\
\text { cepacia }\end{array}$ & $\begin{array}{l}\text { Detergent-based } \\
\text { aqueous two-phase }\end{array}$ & $\begin{array}{l}\text { Saxena } \text { et al. } \\
\text { (2003) }\end{array}$ \\
\hline \hline
\end{tabular}

al., 2006). Several products based on bacterial lipases have been launched successfully in the market in the past few years. A number of such products are from Pseudomonas spp., such as Lumafast and Lipomax with their major application as detergent enzymes, while ChiroCLEC-PC, Chirazyme L-1 and Amano P, P-30 and PS have tremendous potential in organic synthesis (Jones and Richard, 1952).

Lipases in the food. Lipases have broad applications in food industry and they are widely used in the production of variety of products e.g., fruit juices, baked foods, fermented vegetables, cheese, butter and soups. In 1976, Unilever found a method with a mixed hydrolysis and synthesis reaction to produce a cocoabutter substitute using an immobilized lipase. This method is based on an immobilized lipase from Rhizomucor miehei and now used commercially by Quest-Londs Croklaam. This lipase is responsible for a trans esterification reaction replacing palmitic acid in palm oil with stearic acid to form the stearic-oleicstearic triglyceride with the desired melting point for use in chocolate (Sharma et al., 2001; Undurraga et al., 2001; Coleman and Macrae, 1980). The esters produced from short-chain fatty acids have applications as flavouring agents in food industry (Gokbulut and Arslanoglu, 2013). Lipases are also used to give special flavour and taste to food by synthesis of fatty acids and alcohols, which are accepted as flavour and aroma compounds (Gandhi, 1997) for e.g., the lipase enzymes used in dairy industry for the lipolysis of butter fat and cream. Addition of lipases to such products primarily releases short- chain ( $\mathrm{C} 4$ and $\mathrm{C} 6$ ) fatty acids that form sharp flavour but the release of medium-chain (C12 and C14) fatty acids leads to formation of a smooth taste (Saxena et al., 1999). The majority of the commercial lipases are used for flavour development, in dairy products and processing of other foods like meat, vegetables, fruit, baked foods, milk products and beer. Lipases are widely used for the hydrolysis of milk fat in dairy industry. Lipase also enhances cheese ripening and the lipolysis of fat, butter and cream (Sharma et al., 2001).

Lipases in detergents. Lipases are added to detergents used generally in household, industrial laundry and in household dish washers. About 1000 tonnes of lipases are sold annually in this area. Lipases catalyze the breakdown of fatty stains; into hydrophilic parts that are easily removed from similar non-hydrolyzed stains (Joseph et al., 2007). Novo Nordisk, in 1994, introduced 
the first commercial lipase called lipolase TM. Genencor International in 1995 produced two bacterial lipases Lumafast $^{\mathrm{TM}}$ and Lipomax ${ }^{\mathrm{TM}}$ from Pseudomonas mendocina and P. alcaligenes, respectively (Gerritse et al., 1998; Jaeger and Reetz, 1998). Lipases are suitable additives in detergents, because they have both thermophilic 30- $60{ }^{\circ} \mathrm{C}$ and alkalophilic pH 10-11 properties. Moreover, they have the abilities to function in the presence of the various components of washing powder formulations like surfactants and proteases. In addition, they have wide range of substrate specificities to hydrolyze fats of various compositions (Sharma et al., 2001; Jaeger and Reetz, 1998).

Lipases in pulp and paper industry. The main source of paper and pulp industry is wood. Triglycerides and waxes are present in wood, causes serious problems in paper and pulp production. Lipases are used in this industry to remove triglycerides and waxes from pulp, processed for paper making (Table 2). Nippon Paper Industries in Japan introduced a system for the removal of triglycerides from wood based on the lipase of Candida rugosa (Sharma et al., 2001; Gandhi, 1997).

Lipases in leather industry. One of the most important applications of the lipases is to remove subcutaneous fat and hair from animal skin in leather industry. The conventional methods for e.g., surfactants and organic solvents used for this purpose are harmful to environment due to the production of dangerous products such as volatile organic compound (Hasan et al., 2006). On the contrary, lipases are safe, efficient and environmental friendly. Additionally, lipases are used along with other hydrolytic enzymes such as: proteases at alkaline $\mathrm{pH}$ in leather processing are a new approach currently emerging.

Lipases in environmental management. Bioremediation of waste products of lipid processing factories and

Table 2. Industrial application of microbial lipases.

\begin{tabular}{|c|c|c|}
\hline Microorganisms & $\begin{array}{l}\text { Industrial } \\
\text { applications }\end{array}$ & Source \\
\hline $\begin{array}{l}\text { Rhizomucor } \\
\text { miehei }\end{array}$ & Food industry & $\begin{array}{l}\text { Sharma et al. } \\
\text { (2001) }\end{array}$ \\
\hline $\begin{array}{l}\text { Pseudomonas } \\
\text { mendocina }\end{array}$ & $\begin{array}{l}\text { Detergent } \\
\text { industry }\end{array}$ & $\begin{array}{l}\text { Jaeger and Reetz } \\
\text { (1998) }\end{array}$ \\
\hline $\begin{array}{l}\text { Pseudomonas } \\
\text { alcaligenes }\end{array}$ & $\begin{array}{l}\text { Detergent } \\
\text { industry }\end{array}$ & $\begin{array}{l}\text { Gerritse et al. } \\
\text { (1998) }\end{array}$ \\
\hline Candida rugosa & $\begin{array}{l}\text { Paper and } \\
\text { pulp industry }\end{array}$ & $\begin{array}{l}\text { Gandhi } \\
\text { (1997) }\end{array}$ \\
\hline
\end{tabular}

restaurants are carried out by both ex situ and in situ (Pandey et al., 1999).

Lipases in diagnosis. Lipases are used in clinical diagnosis of analytical samples to form glycerol from triacylglycerol which is then quantified either by chemical or enzymic methods. Patients with cardiovascular complaints are diagnosed very accurately with this approach. In this protocol glycerol dehydrogenase catalyze the hydrolysis of lipids by oxidation to produced glycerol. The NADH formed, during this reaction is measured by fluorescence spectroscopy (Benjamin and Pandey, 1997).

Lipases in pharmaceutical industry. Lipases are generally used in pharmaceutical industry for the synthesis of anti tumour agents, alkaloids, antibiotics and vitamins (Jaeger and Eggert, 2002). They are also used in anti-inflammatory drugs such as naproxen, ibuprofen ect. (Xin et al., 2001; Chen and Tsai, 2000; Arroyo et al., 1999; Ducret et al., 1998; Xie et al., 1998; El-Sawah et al., 1995) and antihypertensive agents including angiotensin converting enzyme (ACE) inhibitors such as captopril, enalapril, ceranopril, zofenapril, lisinopril, and the calcium channel- blocking drugs such as diltiazem (Sharma et al., 2001).

\section{Conclusion}

Lipases are an important group of hydrolases which play a key role in transport, digestion and processing of fats oil. Lipases are produced by different biotic agents including bacteria, human being and even viruses. Various purification strategies are discussed in this review for lipases. Due to their activities at different $\mathrm{pH}$ and temperature range, the importance of lipases is increasing day by day in several industries, such as food, detergents, chemicals, pharmaceuticals, etc. to replace the conventional catalyst by bio catalyst which is cheap, safe and environment friendly.

\section{References}

Aires-Barros, M.R., Taipa, M.A., Cabral, J.M.S. 1994. Isolation and purification of lipases. In: LipasesTheir Structere, Biochemistry and Application, P. Wooley and S.B. Petersen (eds.), pp. 243-270, Cambridge University Press, Cambridge, UK.

Albertsson, P.A., Johansson, G., Tjerneld, F. 1990. Aqueous two-phase separations. In: Separation Processes in Biotechnology, J.A. Asenjo (ed.), pp. 287-327, Marcel Dekker, New York, USA. 
Arroyo, M., Montero, J.M.S., Sinisterra, J.V. 1999. Thermal stabilization of immobilized lipase B from Candida antarctica on different supports: Effect of water activity on enzymatic activity in organic media. Enzyme Microbiology Technology, 24: 3-12.

Balashev, K., Jensen, T.R., Kjaer, K., Bjornholm, T. 2001. Novel methods for studying lipids and lipases and their mutual interaction at interfaces, Part I. Atomic force microscopy. Biochimie, 83: 387-397.

Beisson, F., Tiss, A., Rivière, C., Verger, R. 2000. Methods for lipase detection and assay: a critical review. European Journal of Lipid Science and Technology, 102: 133-153.

Benjamin, S., Pandey, A. 1997. Enhancement of lipase production during repeated batch culture using immobilized Candida rugosa. Process Biochemistry, 32: 437-440.

Bornscheuer, U.T., Bessler, C., Srinivas, R., Krishna, S.H. 2002. Optimizing lipases and related enzymes for efficient applications. Trends in Biotechnology, 20: 433-437.

Cai-hong, W., Runfang, G., Hong-wei, Y., Ying-min, J. 2008. Cloning and sequence analysis of a novel cold-adapted lipase gene from strain lip35 (Pseudomonas) sp. Agricultural Sciences in China, 7: 1216-1221.

Chartrain, M., Katz, L., Marcin, C., Thein, M., Smith, S., Fisher, E., Goklen, K., Salmon, P., Brix, T., Price, K., Greasham, R. 1993. Purification and characterization of a novel bioconverting lipase from Pseudomonas aeruginosa MB 5001. Enzyme and Microbial Technology, 15: 575-580.

Chen, J.C., Tsai, S.W. 2000. Enantioselective synthesis of (S)-ibuprofen ester prodrug in cyclohexane by Candida rugosa lipase immobilized on accurel MP1000. Biotechnology Progress, 16: 986-992.

Coleman, M.H., Macrae, A.R. 1980. Fat Process and Composition, UK Patent No.1577933, C1980s.

Dong, H., Gao, S., Han, S., Cao, S. 1999. Purification and characterization of a Pseudomonas sp. Lipase and its properties in non-aqueous media. Biotechnology and Applied Biochemistry, 30: 25-256.

Ducret, A., Trani, M., Lortie, R. 1998. Lipase catalyzed enantioselective esterification of ibuprofen in organic solvent under controlled water activity. Enzyme and Microbial Technology, 22: 212-216.

El-Sawah, M.M., Sherief, A.A., Bayoumy, S.M. 1995. Enzymatic properties of lipase and characteristic production by Lactobacillus delbrueckii subsp. bulgaricus. Antonie Van Leeuwenhoek, 67: $357-$ 362.

Farooqui, A.A., Yang, H.C., Horrock, L.A. 1994. Purification of lipases, phospholipases and kinases by heparin-Sepharose chromatography. Journal of Chromatography A, 673: 149-158.

Gandhi, N.N. 1997. Applications of lipase. Journal of the American Oil Chemists Society, 74: 621-634.

Gerritse, G., Hommes, R.W. J., Quax, W.J. 1998. Development of a lipase fermentation process that uses a recombinant Pseudomonas alcaligenes strain. Applied and Environmental Microbiology, 64: 2644-2651.

Gokbulut, A. A., Arslanoglu, A. 2013. Purification and biochemical characterization of an extracellular lipase from psychrotolerant Pseudomonas fluorescens KE38. Turkish Journal of Biology, 37: 538-546.

Gupta, R., Gupta, N., Rathi, P. 2004. Bacterial lipases: an overview of production, purification and biochemical properties. Applied Microbiology and Biotechnology, 64: 763-781.

Gupta, R., Bradoo, S., Saxena, R.K. 1999. Aqueous two phase systems: an attractive technology for downstream processing of biomolecules. Current Science, 77: 520-523.

Hasan, F., Shah, A.A., Hameed, A. 2006. Industrial applications of microbial lipases. Enzyme and Microbial Technology, 39: 235-251.

Jaeger, K.E., Eggert, T. 2002. Lipases for biotechnology. Current Opinion in Biotechnology, 13: 390-397.

Jaeger, K.E., Reetz, M.T. 1998. Microbial lipases form versatile tools for biotechnology. Trends in Biotechnology, 16: 396-403.

Jaeger, K.E., Ransac, S., Dijkstra, B. W., Colson, C., Heuvel, M.V., Misset, O. 1994. Bacterial lipases. FEMS Microbiology Reviews, 15: 29-63.

Jones, A., Richards, T. 1952. Night blue and Victoria blue as indicators in lipolysis media. Journal of Applied Microbiology, 15: 82-93.

Joseph, B., Ramteke, P.W., Thomas, G., Shrivastava, N. 2007. Standard review cold-active microbial lipases; a versatile tool for industrial applications. Biotechnology and Molecular Biology Review, 2: 39-48.

Kojima, Y., Kobayashi, M., Shimizu, S. 2003. A novel lipase from Pseudomonas fluorescens HU380: gene cloning, overproduction, renaturation-activation, two-step purification, and characterization. Journal of Bioscience and Bioengineering, 96: 242-249. 
Lee, S.Y., Rhee, J.S. 1993. Production and partial purification of a lipase from Pseudomonas putida, 3SK. Enzyme and Microbial Technology, 15: 617623.

Menge, U., Hecht, H.-J., Schomburg, D., Schmid, R.D. Hedrich, H.C., Spener, F. 1991. Crystallization and preliminary X-ray studies of lipase from Geotrichum candidum. In: Lipases: Structure, Mechsanism and Genetic Engineering, L. Alberghina; R.D. Schmid and R.Verger (eds.), 59-62, $1^{\text {st }}$ edition, GBF Monographs no. $16 \mathrm{VCH}$, Weinheim, Germany.

Pabai, F., Kermasha, S., Morin, A. 1995. Interesterification of butter fat by partially purified extracellular lipases from Pseudomonas putida, Aspergillus niger and Rhizopus oryzae. World Journal of Microbiology \& Biotechnology, 11: 669-677.

Palekar, A.A., Vasudevan, P.T., Yan, S. 2000. Purification of lipase: a review. Biocatalysis and Biotransformation, 18: 177-200.

Pandey, A., Benjamin, S., Soccol, C.R., Nigam, P., Krieger, N., Soccol, V.T. 1999. The realm of microbial lipases in biotechnology. Biotechnology Applid Biochemistry, 29: 119-131.

Qamsari, E.M., Kermanshahi, R.K., Nejad, Z.M. 2011. Isolation and identification of a novel, lipase producing bacterium, Pseudomonas aeruginosa KM110. Iranian Journal of Microbiology, 3: 92-98.

Saxena, R.K., Ghosh, P.K., Gupta, R., Davidson, W.S., Bradoo, S., Gulati, R. 1999. Microbial lipases: Potential biocatalysts for the future industry. Current Science, 77: 101-115.

Saxena, R.K., Sheoran, A., Giri, B., Davidson, W. S. 2003. Purification strategies for microbial lipases. Journal of Microbiological Methods, 52: 1-18.

Sharma, R., Chisti, Y., Banerjee, U.C. 2001. Production, purification, characterization, and applications of lipases. Biotechnology Advances, 19: 627-662.

Sharon, C., Furugoh, S., Yamakido, T., Ogawa, H.I., Kato, Y. 1998. Purification and characterization of a lipase from Pseudomonas aeruginosa KKA-5 and its role in castor oil hydrolysis. Journal of Industrial Microbiology and Biotechnology, 20: 304-307.

Stoyanova, V., Stanka, G., Ivan, I., Mariana, M., Sonya, T. 2012. Lipolytic activity of genus Pseudomonas.
Journal of Bioscience and Biotechnology, SE/online 163-168.

Sztajer, H., Bryjak, M. 1989. Capillar membranes for purification of Pseudomonas fluorescens lipase. Bioprocess Engineering, 4: 257-259.

Terstappen, G.C., Geerts, A.J., Kula, M.R. 1992. The use of detergent-based aqueous two-phase systems for the isolation of extracellular proteins: purification of a lipase from Pseudomonas cepacia. Biotechnology and Applied Biochemistry, 16: 228-235.

Underkofler, L.A., Barton, R.R., Rennert, S.S. 1957. Production of microbial enzymes and their applications. Applied Microbiology, 3: 212-221.

Undurraga, D., Markovits, A., Erazo, S. 2001. Cocoa butter equivalent through enzymic interesterification of palm oil mid fraction. Process Biochemistry, 36: 933-939.

Veerapagu, M., Narayanan, A.S., Ponmurugan, K., Jeya, K.R. 2013. Screening selection identification production and optimization of bacterial lipases from oil spilled soil. Asian Journal of Pharmaceutical and Clinical Research, 6: 62-67.

Veeraragavan, K., Colpitts, T., Gibbs, B.F. 1990. Purification and characterization of two distinct lipases from Geotrichum candidum. Biochimica et Biophysica Acta, 1044: 26-33.

Wilke, D. 1999. Chemicals from biotechnology molecular plant genetics will challenge the chemical and fermentation. Applied Microbiology and Biotechnology, 52: 135-145.

Xie, Y.C., Liu, H.Z., Chen, J.Y. 1998. Candida rugosa lipase catalyzed esterification of racemic ibuprofen with butanol; raeemization of R-ibuprofen and chemical hydrolysis of S-ester formed. Biotechnology Letters, 20: 455-458.

Xin, J. Y., Li, S. B., Xu, Y., Chui, J. R. Xia, C. G. 2001. Dynamic enzymatic resolution of naproxen methyl ester in a membrane bioreactor. Journal of Chemical Technology \& $\square$ Biotechnology, 76: 579-585.

Yamamoto, K., Fujiwara, N. 1995. The hydrolysis of castor oil using a lipase from Pseudomonas sp. fB-24 positional and substrate specificity of the enzyme and optimum reaction conditions. Bioscience Biotechnology and Biochemistry, 59: 1262-1266. 